\title{
GEORGIA STATE UNIVERSITY J. Mack Robinson College of Business
}

\author{
Two Faculty Positions in Risk Management
}

The Robinson College of Business at Georgia State University invites applications for two tenure-track positions at the assistant professor level to begin in fall 2004. These two hires are the first of six positions for which we anticipate hiring during the next three years for the purpose of forming a cross-disciplinary group charged to conduct fundamental research on the economics of uncertainty and on the management and pricing of risk.

\section{JOB QUALIFICATIONS:}

Qualified candidates will be expected to possess a $\mathrm{PhD}$ by the time of their appointment. All areas of specialization will be considered provided the candidate has a strong interest in and academic background in some area of risk, broadly defined. We are particularly interested in individuals whose studies involve dynamic asset pricing, computational methods including financial econometrics, statistics or actuarial science, equilibrium theory or the microeconomics of uncertainty, optimal contracting, and the estimation theory for dynamic games and dynamic contracting. The ideal candidate will be expected to publish in the major journals of economics and finance as well as important journals of their specific discipline.

\section{ABOUT THE ENVIRONMENT:}

The Department of Risk Management and Insurance houses one of the oldest and most influential risk management programs in the U.S. Beginning in academic year 2003, and continuing in 2004 and 2005, the department intends to recruit six new faculty members trained in the most advanced methods of their disciplines for a coordinated study of risk management problems at their most fundamental levels. Salaries will be competitive and strong research support will be provided. Teaching loads will be low to ensure the group has the opportunity to produce high quality research. A statement outlining the vision the department has for the group is available upon request from the co-chairs of the recruiting committee.

FURTHER INFORMATION AND APPLICATION PROCEDURE:

Applicants should send a current curriculum vita, three letters of recommendation, and recent publications or working papers for review. Applications should be submitted electronically via e-mail as pdf files to rphillips@gsu.edu. Applicants wishing to send their materials via regular mail should forward them to: 
Richard D. Phillips, Co-chair

Department of Risk Management and Insurance

Robinson College of Business

Georgia State University

P.O. Box 4036

Atlanta, GA 30302-4036

For further information, contact either co-chair of the search committee: Martin Grace-mgrace@gsu.edu or 404-651-2789; Richard Phillips - rphillips@gsu.edu or 404-651-3397.

Interviews can be scheduled for the 2003 Financial Management Association Annual Meeting or the 2004 Allied Social Sciences Association Annual Meeting. Preference will be given to applications received by December 1, 2003.

Georgia State University is AN EQUAL OPPORTUNITY EDUCATIONAL INSTITUTION/AFFIRMATIVE ACTION EMPLOYER AND ENCOURAGES APPLICATIONS FROM Qualified minorities. All Positions are SubJect to Final Approval for FUNDING. 